University of Nebraska - Lincoln

DigitalCommons@University of Nebraska - Lincoln

Publications from USDA-ARS / UNL Faculty

U.S. Department of Agriculture: Agricultural

Research Service, Lincoln, Nebraska

2008

\title{
EPIC Modeling of Soil Organic Carbon Sequestration in Croplands of lowa
}

\author{
Hector J. Causarano \\ USDA-ARS Hydrology and Remote Sensing Lab., Hector.Causarano@ars.usda.gov \\ Paul C. Doraiswamy \\ USDA-ARS Hydrology and Remote Sensing Lab. \\ Gregory W. McCarty \\ USDA-ARS Hydrology and Remote Sensing Lab. \\ Jerry L. Hatfield \\ USDA-ARS National Soil Tilth Research Lab., jerry.hatfield@ars.usda.gov \\ Sushil Milak \\ USDA-ARS Hydrology and Remote Sensing Lab. \\ See next page for additional authors
}

Follow this and additional works at: https://digitalcommons.unl.edu/usdaarsfacpub

Causarano, Hector J.; Doraiswamy, Paul C.; McCarty, Gregory W.; Hatfield, Jerry L.; Milak, Sushil; and Stern, Alan J., "EPIC Modeling of Soil Organic Carbon Sequestration in Croplands of lowa" (2008). Publications from USDA-ARS / UNL Faculty. 1363.

https://digitalcommons.unl.edu/usdaarsfacpub/1363

This Article is brought to you for free and open access by the U.S. Department of Agriculture: Agricultural Research Service, Lincoln, Nebraska at DigitalCommons@University of Nebraska - Lincoln. It has been accepted for inclusion in Publications from USDA-ARS / UNL Faculty by an authorized administrator of DigitalCommons@University of Nebraska - Lincoln. 
Authors

Hector J. Causarano, Paul C. Doraiswamy, Gregory W. McCarty, Jerry L. Hatfield, Sushil Milak, and Alan J. Stern 


\section{EPIC Modeling of Soil Organic Carbon Sequestration in Croplands of lowa}

\section{Hector J. Causarano, ${ }^{*}$ Paul C. Doraiswamy, Gregory W. McCarty, Jerry L. Hatfield, Sushil Milak, and Alan. J. Stern USDA-ARS}

Depending on management, soil organic carbon (SOC) is a potential source or sink for atmospheric $\mathrm{CO}_{2}$. We used the EPIC model to study impacts of soil and crop management on SOC in corn (Zea mays L.) and soybean (Glycine max L. Merr.) croplands of Iowa. The National Agricultural Statistics Service crops classification maps were used to identify corn-soybean areas. Soil properties were obtained from a combination of SSURGO and STATSGO databases. Daily weather variables were obtained from first order meteorological stations in Iowa and neighboring states. Data on crop management, fertilizer application and tillage were obtained from publicly available databases maintained by the NRCS, USDA-Economic Research Service (ERS), and Conservation Technology Information Center. The EPIC model accurately simulated state averages of crop yields during $1970-2005\left(R^{2}=0.87\right)$. Simulated SOC explained $75 \%$ of the variation in measured SOC. With current trends in conservation tillage adoption, total stock of SOC $(0-20 \mathrm{~cm})$ is predicted to reach $506 \mathrm{Tg}$ by 2019 , representing an increase of $28 \mathrm{Tg}$ with respect to 1980 . In contrast, when the whole soil profile was considered, EPIC estimated a decrease of SOC stocks with time, from $1835 \mathrm{Tg}$ in 1980 to $1771 \mathrm{Tg}$ in 2019. Hence, soil depth considered for calculations is an important factor that needs further investigation. Soil organic C sequestration rates $(0-20 \mathrm{~cm})$ were estimated at 0.50 to $0.63 \mathrm{Mg} \mathrm{ha}^{-1} \mathrm{yr}^{-1}$ depending on climate and soil conditions. Overall, combining land use maps with EPIC proved valid for predicting impacts of management practices on SOC. However, more data on spatial and temporal variation in SOC are needed to improve model calibration and validation.
Copyright $\odot 2008$ by the American Society of Agronomy, Crop Science Society of America, and Soil Science Society of America. All rights reserved. No part of this periodical may be reproduced or transmitted in any form or by any means, electronic or mechanical, including photocopying, recording, or any information storage and retrieval system, without permission in writing from the publisher.

Published in J. Environ. Qual. 37:1345-1353 (2008).

doi:10.2134/jeq2007.0277

Received 30 May 2007.

*Corresponding author (Hector.Causarano@ars.usda.gov). ( ) ASA, CSSA, SSSA

677 S. Segoe Rd., Madison, WI 53711 USA
$\mathrm{T}$ HE largest percentage of Iowa's farmland $(76 \%)$ is devoted to croplands. Principal crops are corn and soybean, accounting for $92 \%$ of croplands and placing lowa as the top corn and soybean producing state in the USA (USDA-NASS, 2002 and 2007).

Depending on management, soil organic carbon (SOC) is a source or a sink for atmospheric $\mathrm{CO}_{2}$ (Follett, 2001; Lal, 2002). Conservation tillage (i.e., maintaining at least $30 \%$ of the soil surface covered by residue after planting) is recognized as an effective technology for reducing SOC losses and sequestering atmospheric $\mathrm{CO}_{2}$.

The rate of SOC storage after conversion from conventional tillage (CT) to no tillage (NT) in corn-soybean rotations of the Corn Belt is highly variable. Six studies in Indiana, Illinois, and Ohio had average values ( \pm SD) of $0.54 \pm 0.36 \mathrm{Mg} \mathrm{C} \mathrm{ha}^{-1} \mathrm{yr}^{-1}$ in the top $30 \mathrm{~cm}$ (Johnson et al., 2005). The one study from Iowa (Nashua) had a sequestration rate of $0.72 \mathrm{Mg} \mathrm{C} \mathrm{ha}^{-1} \mathrm{yr}^{-1}$ (continuous corn, $0-20 \mathrm{~cm}$ ). More information on the impacts of NT adoption in the Corn Belt is needed.

The integration of a properly validated mechanistic model of crop growth and cropping systems with field experiments and a geographic information system database would be a sound approach for analyzing the interactive effects of climate, soils, and management practices on SOC at the regional scale (Paustian et al., 1995). Two recent studies have followed this approach but have obtained contrasting results. Paustian et al. (2002) found increases in SOC for common cropping systems of Iowa. However, Potter et al. (2006) found that most cropland areas in Iowa have significant losses of SOC. The two modeling efforts differed in many aspects. Paustian et al. (2002) used the Century model (Parton et al., 1987). Counties were assumed homogeneous with respect to climate variables; soil data were derived from the state soil geographic (STATSGO) database and were grouped according to surface texture $(0-20 \mathrm{~cm})$ and drainage class (hydric or non-hydric). Potter et al. (2006) used the EPIC (Environmental Policy Integrated Climate) v3060 model (Izaurralde et al., 2006) and the 1997 National Resources Inventory as a framework for simulations, applying clustering techniques to group climate and soils with similar characteristics.

Potter et al. (2006) concluded the following as main causes for estimates of SOC losses in their study: (i) Within EPIC, SOC

H.J. Causarano, P.C. Doraiswamy, G.W. McCarty, S. Milak, and A.J. Stern, USDA-ARS Hydrology and Remote Sensing Lab., Bldg 007, Rm 104, BARC-West, 10300 Baltimore Avenue, Beltsville, MD 20705. J.L. Hatfield, USDA-ARS National Soil Tilth Research Lab., Room 108, 2150 Pammel Drive, Ames, IA 50011.

\footnotetext{
Abbreviations: $\mathrm{CT}$, conventional tillage; DMLA, maximum potential leaf area index; EPIC, Environmental Policy Integrated Climate; HI, harvest index; NT, no tillage; RT, reduced tillage; SOC, soil organic carbon; SSURGO, soil survey geographic; STATSGO, state soil geographic; WA, biomass to energy ratio; WAC2, value of $\mathrm{CO}_{2}$ concentration and corresponding value of the parameter WA.
} 
may be transported off the field by wind and water erosion or can be leached, whereas Century used by Paustian et al. (2002) does not account for losses from the system; (ii) Potter et al. (2006) did not simulate crop rotations or cover crops, whereas Paustian et al. (2002) did; (iii) some model runs were affected by under-fertilization; and (iv) Potter et al. (2006) assumed good drainage conditions and therefore that the increased SOC decomposition resulted from optimum aeration.

Developing databases for the regional assessment of SOC and establishing procedures for aggregating data are critical steps that influence simulation outcomes. We developed a detailed and computationally intensive approach for integrating the EPIC v3060 model with soil and climate data; model simulations were conducted at a grid-cell level of $1.6 \times 1.6 \mathrm{~km}\left(1 \mathrm{mi}^{2}\right)$. With this approach, we assessed the long-term impacts of tillage practices on SOC to a depth of $20 \mathrm{~cm}$ and to the soil profile in Iowa. Our objectives were (i) to assess current SOC stocks in corn-soybean croplands, (ii) to calculate potential $\mathrm{C}$ sequestration with increasing adoption of conservation tillage, (iii) to estimate current SOC sequestration rates, and (iv) to determine areas in Iowa where the positive impact of conservation tillage is the greatest.

\section{Materials and Methods}

\section{Study Area}

Mean annual temperature in Iowa increases from $7.5^{\circ} \mathrm{C}$ in the north to $9.5^{\circ} \mathrm{C}$ in the south. Mean annual precipitation increases from $660 \mathrm{~mm}$ in the northwest to $970 \mathrm{~mm}$ in the southeast (SCAS, 2005). Dominant soils in croplands are Mollisols (Hapludolls, Argiudolls, Endoaquolls, Argiaquolls) and Alfisols (Hapludalfs). Mollisols have high SOC content in the surface horizon $(>2.5 \%)$ and high base saturation (>50\%) in all horizons. Alfisols have less SOC content than Mollisols but are similarly rich in bases. These soils vary from well drained to poorly drained. Field drainage (e.g., tile drain) is used extensively over the state.

\section{Model Description}

We used EPIC v3060, which is a process-based model that describes climate-soil-management interactions, to simulate crop production and SOC. The model operates on a daily time step and can execute long-term simulations (hundreds of years) on catchments up to 100 ha. Twelve plant species can be modeled at the same time, allowing intercrop and covercrop mixtures. Simulated processes include tillage effects on crop residues and bulk density, wind and water erosion, and hydrology. The model also simulates soil temperature and heat flow; C, N, and P cycling; fertilizer and irrigation effects on crops; pesticide fate; and economics. The model was developed in the 1980s (Williams, 1990) to simulate erosion impacts on crop productivity. It has been widely tested and adapted (Gassman et al., 2004). The original C routine in EPIC was simple and a function of $\mathrm{N}$ levels. Recent modifications for handling SOC dynamics are by a process similar to that in the Century model (Izaurralde et al., 2006). This revised EPIC has been successfully calibrated against data from a 61-yr experiment near Breton, Canada, and from five agri- cultural sites converted to permanent cover in Texas, Kansas, and Nebraska (Izaurralde et al., 2006).

In EPIC, crop growth is simulated by functions that convert a fraction of solar radiation into plant biomass on a daily basis. Potential plant growth is affected by ambient vapor pressure, $\mathrm{CO}_{2}$ concentration, and stresses (water, temperature, $\mathrm{N}, \mathrm{P}$, and aeration). A fraction of daily biomass growth is partitioned to roots. Root growth is affected by soil strength, aluminum content, and temperature. Daily weather can be input or estimated from long-term weather statistics (Williams, 1990). Soil organic $\mathrm{C}$ is simulated by functions that convert crop residues, roots, and organic amendments added to the soil into three compartments with different turnover times: microbial biomass (days or weeks), slow humus (few years), and passive humus (hundreds of years). Carbon can also be lost in the form of leachates, eroded sediments, or $\mathrm{CO}_{2}$ (Izaurralde et al., 2006).

\section{Model Inputs}

The input database for the state of Iowa was developed by the aggregation of $256 \mathrm{ha}\left(1 \mathrm{mi}^{2}\right)$ sub-areas (or pixels) that had $>50 \%$ corn and soybean in 2005 . There were 28,620 subareas representing 7.3 million hectares of croplands in Iowa. The procedure for defining sub-areas is discussed below. We simulated crop yields and SOC on the 0- to 20-cm depth.

Definition of Sub-areas and Acquirement of Soil Properties Data

The two publicly available soil survey databases for Iowa are STATSGO and the soil survey geographic database (SSURGO). The STATSGO soil survey covers the state at the 1:250,000 scale and consists of soil association units having 10 to 20 components (different soils). The SSURGO survey covers individual counties at the 1:24,000 scale and can have 1 to 3 components per map unit. We used SSURGO data when possible because it has higher detail than STATSGO. SSURGO data were available in 87 out of 99 counties. The 12 counties without SSURGO data were Mitchell, Howard, Plymouth, Webster, Cass, Adair, Madison, Mahaska, Keokuk, Wayne, Appanoose, and Davis.

For counties with SSURGO, bulk density, sand and silt content, $\mathrm{pH}$, organic carbon content, calcium carbonate content, and cation exchange capacity were obtained as follows: (i) Weighted averages for each soil property were calculated for 0 - to $0.2-, 0.2$ - to 0.6-, 0.6- to 1.0-, and 1.0- to 1.5-m depths within each component of a map unit. (ii) All components of a map unit (including slope) were aggregated by computing weight averages based on weigh factors provided for each component. (iii) Land use map (crop classification) developed by USDA-NASS at $30 \mathrm{~m}$ pixels was aggregated to $250-\mathrm{m}$ pixels. Pixels having $>90 \%$ corn-soybean crop area were masked. (iv) Map units were intercepted with the masked land use map, and individual soil properties were aggregated (weighted by area) to represent the 250-m pixels. (v) Masked 250 -m pixels of soil properties were aggregated to $1600-\mathrm{m}$ pixels $\left(1 \mathrm{mi}^{2}\right)$ if 21 out of 40 had corn-soybean. This assured that only 1600 -m pixels with $>50 \%$ corn and soybean area were included in the simulations. Aggregation from 250 to $1600 \mathrm{~m}$ pixel was done by computing the arithmetic average of components pixels. A schematic of the described procedure is shown in Fig. 1. 


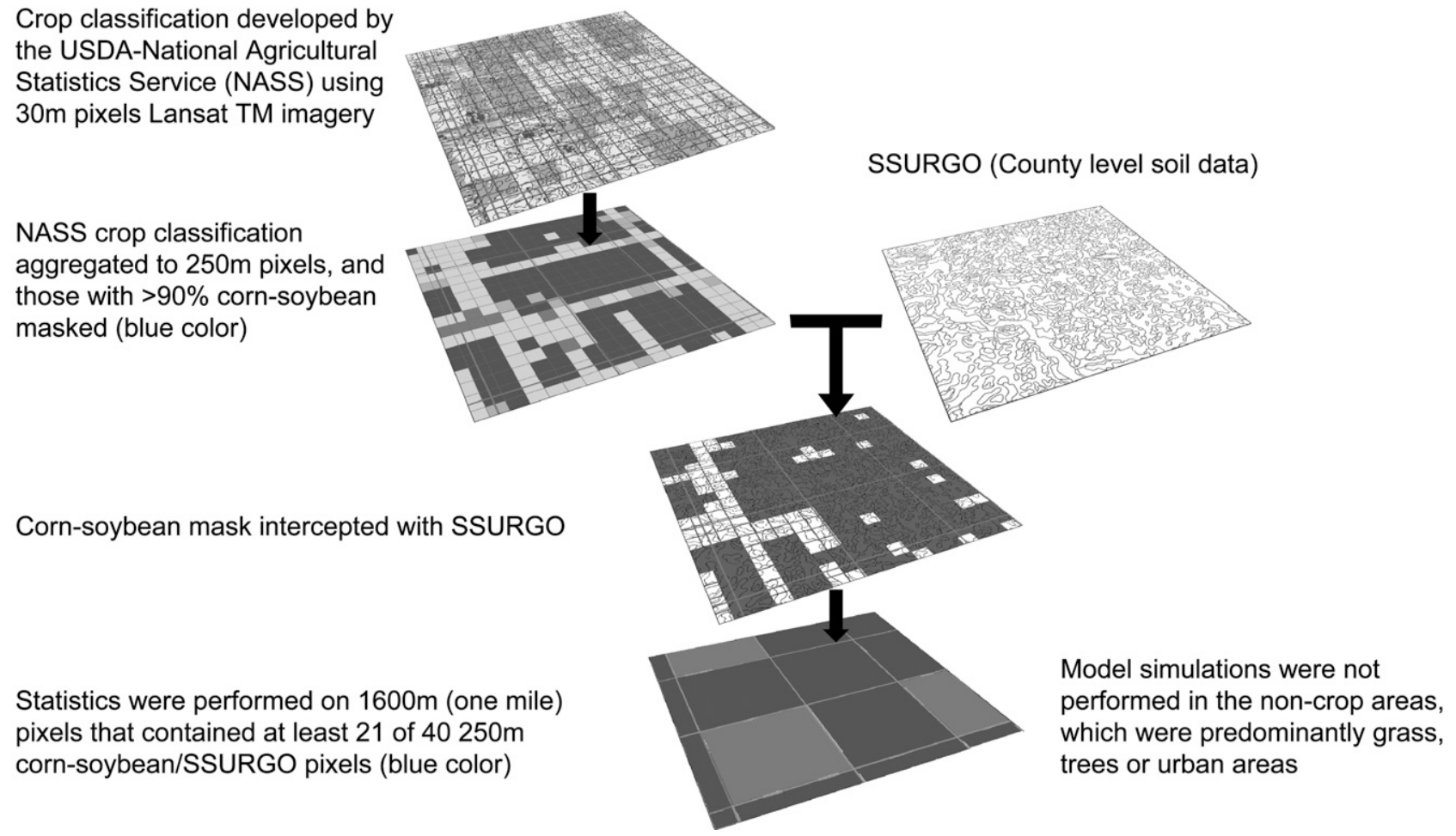

Fig. 1. Schematic of the procedure used for defining simulation sub-areas (pixels) and extracting soil properties data from the SSURGO database.

For counties without SSURGO data, STATSGO map units were overlaid on a 250-m pixel grid (using step iv above), and the intercepted soil properties were extended to the STATSGO map unit. As an example, to get the average of a particular STATSGO map unit, we considered all occurrences where there is $250-\mathrm{m}$ pixel data overlapping with the STATSGO map unit. In general, a STATSGO map unit extends on more than one county.

Slope and slope length were obtained from the SSURGO database with a procedure similar to other soil properties (horizon depths are not considered in this case). Most fields in Iowa had some form of drainage (tile drain was common), but more detailed information was not available. We assumed that soils used in our simulations were adequately drained, which is expected for fields where corn or soybean crops were cultivated.

\section{Weather Data}

An interpolated $10-\mathrm{km}$ grid of daily weather inputs (1970-2005) was created using the topogrid command in ArcInfo (ver. 9.4, 2006; ESRI, Redlands, CA). Daily weather data of maximum temperature, minimum temperature, and precipitation were from approximately 100 first-order climate stations operated by the National Oceanic and Atmospheric Administration in Iowa and neighboring states. Daily solar radiation, wind speed, and relative humidity data were generated using WXGEN (weather generator developed for EPIC), based on climate norms of 19 weather stations relatively evenly distributed within the study area. Simulations for the period 2006-2019 were conducted with measured weather data from the period 2005-1992.

During the 36-yr period (1970-2005), annual precipitation in central Iowa (Story County) ranged from $403 \mathrm{~mm}$ in
1975 to $1338 \mathrm{~mm}$ in 1993 . During the same period, annual means of maximum air temperature ranged from $12.9^{\circ} \mathrm{C}$ in 1993 to $17.1^{\circ} \mathrm{C}$ in 1987 ; and minimum air temperature ranged from $1.7^{\circ} \mathrm{C}$ in 1996 to $5.2^{\circ} \mathrm{C}$ in 1987 . Monthly weather variables are presented in Table 1.

\section{Management Practices}

We concentrated our simulation efforts on areas planted with corn or soybean because these two crops cover $92 \%$ of the cropland in Iowa. Because these crops are usually cultivated in rotation, we assumed a single corn-soybean rotation throughout the simulation period. Data on tillage equipment and dates for tillage operations, planting, fertilization, and harvesting were obtained from the RUSLE 2 database (ver. 1.25, 2005; NRCS). Planting density was obtained from Iowa State University extension pamphlets (Iowa State University, 2007).

From 1970 to 1981, management practices were identical for all simulations, and CT operations were simulated (i.e., moldboard plowing after harvest of previous crop, tandem disk, and field cultivator before planting). Beginning 1982, three tillage practices were simulated for each sub-area (pixel): CT, NT, and reduced tillage (RT). Under NT management, crops were directly seeded without tillage operations. Reduced tillage was simulated as soybean planted using one disk operation and corn planted in no-till over soybean residues. A representation of the CT system is presented in Table 2.

Fertilizer application rates for corn and soybean during the period 1970-2005 was obtained from the Economic Research Service (USDA-ERS, 2007). For corn, these data showed that $\mathrm{N}$ application was $120 \mathrm{~kg} \mathrm{ha}^{-1}$ in 1970 and increased linearly at an annual rate of $3 \mathrm{~kg} \mathrm{ha}^{-1}$ until 1980; from 1980, $\mathrm{N}$ ap- 
Table 1. Mean monthly weather variables (1970-2005) in central lowa (Story County).

\begin{tabular}{|c|c|c|c|c|c|c|c|c|c|c|c|c|}
\hline Variable & Jan. & Feb. & Mar. & Apr. & May & June & July & Aug. & Sept. & Oct. & Nov. & Dec. \\
\hline Solar radiation, $\mathrm{MJ} \mathrm{m}^{-2}$ & 7.4 & 10.8 & 14.4 & 17.2 & 20.3 & 23.0 & 22.7 & 19.7 & 15.6 & 11.4 & 7.7 & 6.1 \\
\hline Maximum temperature, ${ }^{\circ} \mathrm{C}$ & -2.3 & 1.0 & 7.8 & 16.1 & 22.2 & 27.4 & 29.5 & 28.2 & 24.4 & 17.5 & 7.9 & 0.2 \\
\hline Minimum temperature, ${ }^{\circ} \mathrm{C}$ & -12.8 & -9.6 & -3.4 & 3.1 & 9.4 & 14.8 & 17.3 & 15.8 & 10.8 & 4.1 & -2.6 & -9.5 \\
\hline Precipitation, $\mathrm{mm}$ & 17.6 & 20.9 & 47.0 & 72.5 & 102.2 & 107.7 & 100.5 & 99.6 & 70.4 & 54.0 & 48.9 & 23.5 \\
\hline Relative humidity & 0.8 & 0.7 & 0.6 & 0.6 & 0.6 & 0.6 & 0.6 & 0.7 & 0.6 & 0.6 & 0.7 & 0.7 \\
\hline Wind speed, $\mathrm{m} \mathrm{s}^{-1}$ & 5.2 & 5.1 & 5.7 & 5.9 & 5.0 & 4.7 & 3.9 & 4.0 & 4.2 & 4.8 & 5.5 & 5.2 \\
\hline
\end{tabular}

plications remained at approximately $150 \mathrm{~kg} \mathrm{ha}^{-1} \mathrm{yr}^{-1}$. Applications of $\mathrm{P}$ and $\mathrm{K}$ were fairly constant through the period 1970-2005, with application rates of 30 and $60 \mathrm{~kg} \mathrm{ha}^{-1} \mathrm{yr}^{-1}$ for $\mathrm{P}$ and $\mathrm{K}$, respectively. For soybean, application rates also remained fairly constant at $0-30-60 \mathrm{~kg} \mathrm{ha}^{-1} \mathrm{yr}^{-1}$ of $\mathrm{N}, \mathrm{P}$, and K, respectively, during 1970-2005.

Level of adoption of the three simulated tillage practices at the state level were obtained from the National Crop Residue Management Survey (CTIC, 2005). This information was used to compute the probability associated with each simulated tillage practice and to calculate a weighted average of model outputs. Plots of CTIC estimations are presented in Fig. 2. Sigmoidal functions were fitted to $\mathrm{CT}$ and RT data:

$$
y=\alpha /\{1+\exp [-(x-\beta) / \gamma]\}
$$

where $\mathrm{y}$ is the percentage area under a particular tillage practice; $\mathrm{x}$ is year; and $\alpha, \beta$, and $\gamma$ are parameters.

Conservation tillage was calculated as $100-\mathrm{CT}-\mathrm{RT}$. We considered NT a proxy for conservation tillage.

According to CTIC estimation trends, the percentage area under $\mathrm{CT}$ and RT will have a continuous decrease, with CT decreasing at a higher rate than RT. Conservation tillage is predicted to have a continuous increase, covering approximately $77 \%$ of the croplands in 2019 . Data from CTIC do not give an indication of how long a tillage system has been used; in other words, percentages plotted in Fig. 2 cannot be considered a continuous application of a particular tillage system at a given field site.

Table 2. Representation of management operations with conventional tillage on the corn-soybean rotation used for EPIC simulations in lowa.

\begin{tabular}{|c|c|c|c|}
\hline Date & Field operation & Crop & Additional information \\
\hline 1 Nov. 1969 & moldboard plow & soybean & \\
\hline 10 May 1970 & tandem disk & corn & \\
\hline 20 May 1970 & field cultivator & corn & \\
\hline 21 May 1970 & planting & corn & $\begin{array}{l}\text { potential heat units }= \\
1800,8 \text { plants } \mathrm{m}^{-2}\end{array}$ \\
\hline 21 May 1970 & fertilizer application & corn & $\begin{array}{l}120-30-60 \mathrm{~kg} \mathrm{ha}^{-1} \\
\text { of N-P-K }\end{array}$ \\
\hline 25 Oct. 1970 & harvesting & corn & \\
\hline 1 Nov. 1970 & moldboard plow & corn & \\
\hline 26 May 1971 & tandem disk & soybean & \\
\hline 5 June 1971 & field cultivator & soybean & \\
\hline 6 June 1971 & planting & soybean & $\begin{array}{l}\text { potential heat units }= \\
1300,35 \text { plants } \mathrm{m}^{-2}\end{array}$ \\
\hline 6 June 1971 & fertilizer application & soybean & $\begin{array}{l}0-20-50 \mathrm{~kg} \mathrm{ha}^{-1} \\
\text { of N-P-K }\end{array}$ \\
\hline 30 Oct. 1971 & harvesting & soybean & \\
\hline
\end{tabular}
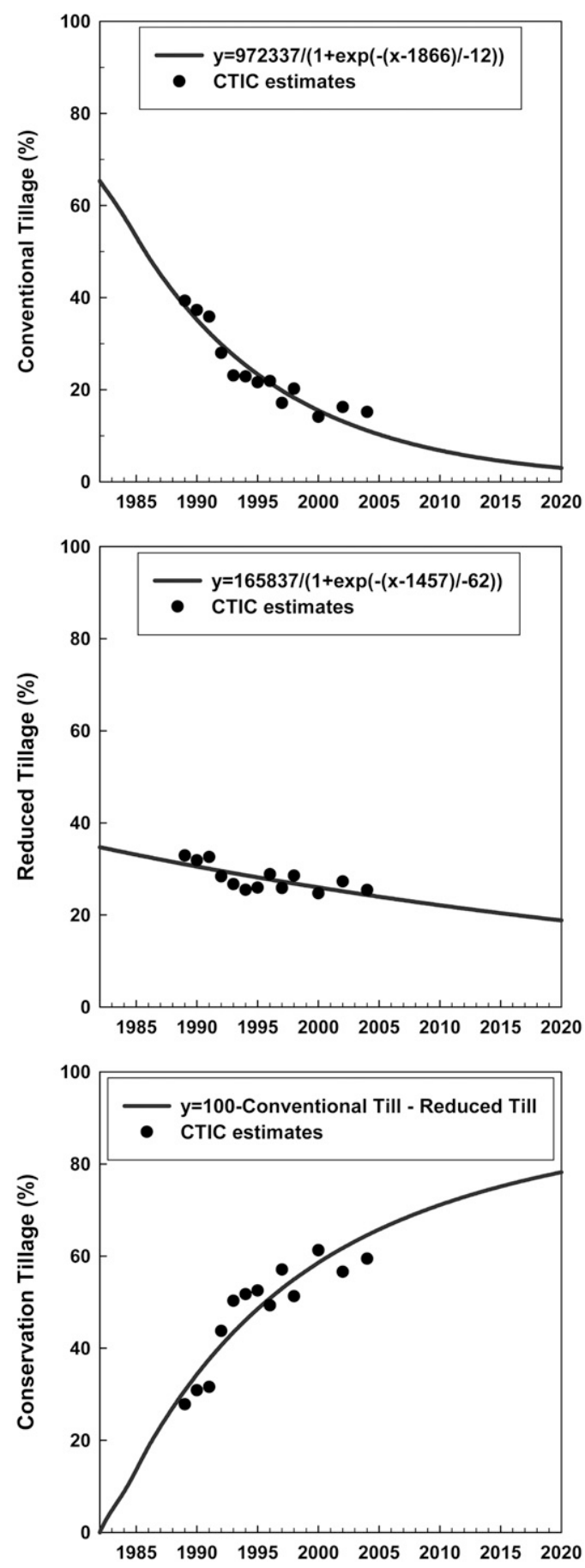

Fig. 2. Adoption of conventional tillage, reduced tillage, and conservation tillage in the state of lowa. Dots are Conservation Tillage Information Center (CTIC) estimates; solid lines are the estimated adoption of a particular tillage system. 


\section{Model Calibration and Validation}

The calibration process focused on the crop growth and SOC modules with data from Boone County. Simulated crop yields were compared against NASS estimated yields for Corn and Soybean growing in Boone County during the period 1970-2004 (USDA-NASS, 2007). Adjustments were made to five crop parameters (biomass to energy ratio, harvest index $[\mathrm{HI}]$, maximum crop height, maximum potential leaf area index, and $\mathrm{CO}_{2}$ concentration in future atmosphere). Simulated SOC $(0-20 \mathrm{~cm})$ for a $1600-\mathrm{m}$ pixel in Boone County was compared with unpublished experimental data (Jerry Ritchie and Cynthia Cambardella, personal communication), no adjustment was required on SOC model parameters.

The validation process consisted of comparing simulated crop yields averaged at the state level against published average yields for the state of Iowa (USDA-NASS, 2007). We also validated the SOC module against experimental data in Iowa.

\section{Results and Discussion}

\section{Model Calibration}

The biomass to energy ratio (WA) and HI are known EPIC parameters influencing crop yields (Wang et al., 2005). The biomass to energy ratio is defined as the potential growth rate per unit of intercepted photosynthetically active radiation, and $\mathrm{HI}$ is the ratio of economic yield to above-ground biomass. We adjusted these two parameters in two opportunities during the simulations to account for changes in crop varieties (Table 3). In addition, the other two corn parameters were adjusted in 1995 to reflect new varieties: the maximum crop height and the maximum potential leaf area index (DMLA). Our simulations also considered future $\mathrm{CO}_{2}$ concentrations in the atmosphere and their impacts on radiation use efficiency of soybean and corn. For this, the parameter WAC2, representing the value of $\mathrm{CO}_{2}$ concentration and the corresponding value of the parameter WA, was adjusted (Table 3). The value on the left of the decimal (in parameter WAC2) is the value of $\mathrm{CO}_{2}$ concentration, and the value on the right of the decimal is the corresponding value of the parameter WA. Parameters in the SOC sub-model were not adjusted (i.e., default values were used).

Crops parameters were consistent with reports in the literature. The corn WA value of 35 is similar to values reported by Wang et al. (2005) and Causarano et al. (2007). Likewise, the corn WA value of 45 is similar to a calculated value from data reported by Kiniry et al. (2004), Lindquist et al. (2005), and Tollenaar and Aguilera (1992). The corn HI value of 0.5 is similar to values reported in agronomic studies in the USA (Kiniry et al., 1997), and the corn HI of 0.6 is similar to Westgate et al. (1997). The corn DMLA of 6.0 is close to values found by Kiniry et al. (2004). Soybean WA and HI are within the range reported by Kiniry et al. (1992). The soybean DMLA of 4.5 agrees with Pedersen and Lauer (2004).

A comparison of EPIC simulated crop yields against NASS estimations for Boone County, during the period 1970-2005, is presented in Fig. 3. Historical crop yield data show year-to-
Table 3. Parameters in EPIC crop sub-model adjusted during the calibration phase for simulation of corn and soybean yields in lowa.

\begin{tabular}{|c|c|c|c|c|}
\hline \multirow{2}{*}{ Parameter } & \multicolumn{2}{|c|}{ 1970-1994 } & \multicolumn{2}{|c|}{ 1995-2019 } \\
\hline & Soybean & Corn & Soybean & Corn \\
\hline $\begin{array}{l}\text { Biomass-energy ratio (WA), } \\
\mathrm{kg} \mathrm{ha}^{-1} \mathrm{MJ}^{-1}\end{array}$ & 23 & 35 & 27 & 45 \\
\hline Harvest index & 0.3 & 0.5 & 0.3 & 0.6 \\
\hline Maximum crop height, $\mathrm{m}$ & 0.8 & 2.6 & 0.8 & 3.0 \\
\hline Maximum potential leaf area index & 4.5 & 4.5 & 4.5 & 6.0 \\
\hline Effect of $\mathrm{CO}_{2}$ on WA (WAC2) & 660.31 & 660.45 & 660.31 & 660.45 \\
\hline
\end{tabular}
$\mu \mathrm{L} \mathrm{L}^{-1} \mathrm{~kg} \mathrm{ha}^{-1} \mathrm{MJ}^{-1}$

t In parameter WAC2, the value on the left of the decimal is the value of $\mathrm{CO} 2$ concentration, and the value on the right of the decimal is the corresponding value of the parameter WA.

year variability due to weather conditions. Also, historical data seemed to indicate yield improvements due to better technology, most probably seed varieties, which became apparent beginning in 1993 for corn and in 1995 for soybean. Overall, EPIC predicted corn and soybean yields with acceptable accuracy. Twelve out of 18 simulation runs had corn predicted yields within $20 \%$ of NASS estimations, and 15 out of 18 runs had soybean predicted yields within $20 \%$ of NASS estimated yields. The EPIC model has been shown to accurately
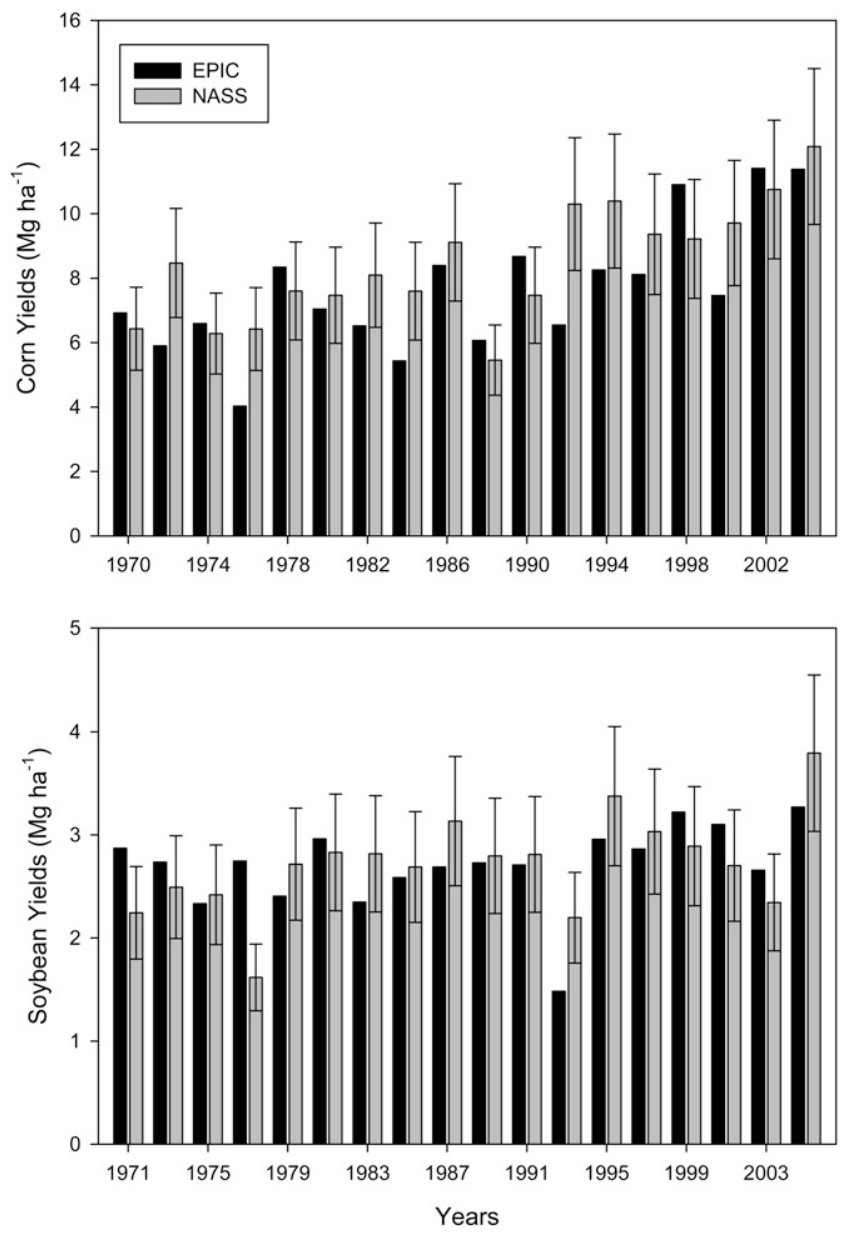

Fig. 3. Comparison of EPIC (Environmental Policy Integrated Climate) simulated yields and National Agricultural Statistics Service (NASS) estimated yields for corn and soybean growing in Boone County during the period 1970-2004. Error bars are $20 \%$ of NASS estimated yields. 


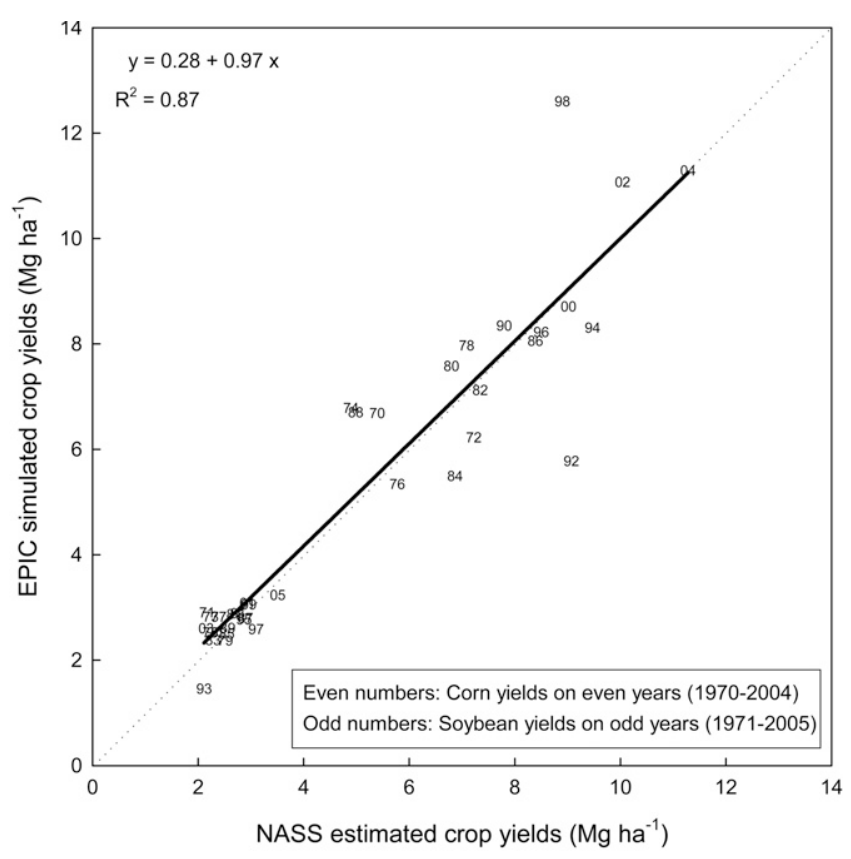

Fig. 4. Comparison of simulated and National Agricultural Statistics Service (NASS) estimated average yields of corn and soybean in the state of lowa during the period 1970-2005. The slope and intercept of the regression line are not significantly different from 1 and 0 , respectively. EPIC, Environmental Policy Integrated Climate.

simulate long-term mean yields but may be less accurate for predicting year-to-year variability (Kiniry et al., 1995).

\section{Model Validation}

During the 36-yr period (1970-2005), simulated yield explained $87 \%$ of the variation in NASS estimated corn and soybean yields for the state of Iowa (Fig. 4). The slope and intercept of the regression line were not significantly different from 1 and 0 , respec-

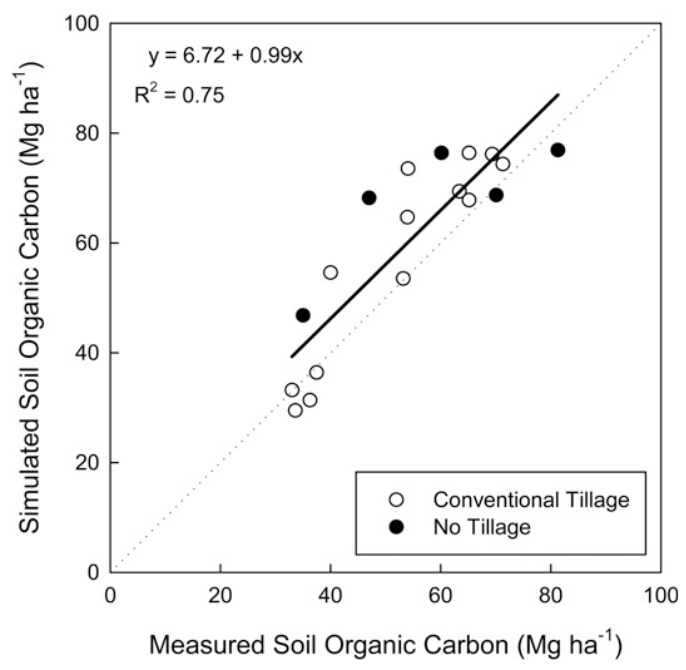

Fig. 5. Comparison of EPIC (Environmental Policy Integrated Climate) simulated and measured soil organic carbon for the 0 - to $20-\mathrm{cm}$ depth. The slope and intercept of the regression line are not significantly different from 1 and 0 , respectively. Measured data are from Al Kaisi and Yin (2005), Al Kaisi et al. (2005), Cynthia Cambardella (unpublished), Jerry Ritchie (unpublished), Karlen et al. (1998), and Moorman et al. (2004). tively. Overall, EPIC simulations were adequate; $72 \%$ of simulated corn yields and $78 \%$ of simulated soybean yields were within $20 \%$ of NASS estimated yields. Part of the disagreement between simulated and estimated yields in Fig. 4 is due to the fact that simulated yields are from CT management, although estimated yields implicitly accounted for the effect of conservation practices on crop yields. Also, our simulations considered a corn-soybean rotation, although other rotations (or even mono-crop) involving corn and soybean exist. Simulations at larger scales (counties or sub-counties) might not be as accurate. We did not have such high-detailed measured data to validate our simulations.

The EPIC model performed well in simulating SOC (Fig. 5). Measured SOC values are from experiments comparing CT and NT with corn-soybean rotation in the northeast (Karlen et al., 1998), northwest (Al Kaisi et al., 2005), mid-central (Cynthia Cambardella and Jerry Ritchie, unpublished), southwest (Moorman et al., 2004; Al Kaisi et al., 2005), and southeast Iowa (Al Kaisi et al., 2005). The EPIC simulated values correspond to the closest pixel to each measured data. Simulated SOC explained $75 \%$ of the variation in measured SOC. The slope and intercept of the regression line were not significantly different from 1 and 0 , respectively. There were no detailed information on historical land use and management on the published literature. Our simulations used the generic management files described in the Materials and Methods section. Thus, apart from incorrect parameterization, inappropriate initialization of the model and the scaling factor (256-ha pixel) could have contributed to biases. Overall, EPIC simulations were more accurate for estimating SOC under CT $(n=13)$ than under NT $(n=5)$. More temporal and spatially distributed field data under different tillage practices are needed for a better assessment of EPIC performance with respect to SOC simulations in the different geographical regions of Iowa.

\section{Effects of Tillage Practices on Soil Organic Carbon $(0-20 \mathrm{~cm})$}

Continuous use of CT caused decreases in SOC stocks, as indicated by the simulated SOC to a depth of $20 \mathrm{~cm}$ (Fig. 6). Simulated SOC under CT decreased from $72 \mathrm{Mg} \mathrm{ha}^{-1}$ in 1970 to $57 \mathrm{Mg} \mathrm{ha}^{-1}$ in 2019. On the other hand, changes in tillage management in 1981 caused a slightly increase in SOC stocks with RT, resulting in $66 \mathrm{Mg} \mathrm{ha}^{-1}$ in 2019, and a significant increase with NT, resulting in $78 \mathrm{Mg} \mathrm{ha}^{-1}$ in 2019. The EPIC model simulates several processes involved in organic carbon flows. Some simulated processes are mixing of nutrients and crop residues, changes in bulk density, conversion of standing residue to flat residue, ridge height and surface roughness, daily soil temperature and water content for each horizon, wind and water erosion, and leaching of dissolved organic carbon (Izaurralde et al., 2006). The increase in SOC with reducing tillage intensity is the result of the interaction effect of decreasing crop residue decomposition and decreasing soil erosion because more residue is left on the soil surface. We assumed that all croplands in Iowa would be maintained under a particular tillage practice. This hypothetical scenario may be unlikely, but in the absence of a better spatial database on tillage practices we used this assumption. Economical considerations, government incentives, and environmental concerns induce producers to adopt con- 
servation tillage practices, but weeds, insects, disease infestations, or soil problems (e.g., compaction and drainage) may result in their decision to return to infrequent CT operations. Thus, a more realistic scenario at the state level is the one whereby all possible tillage practices coexist but with different levels of adoption.

\section{Simulated Changes in Soil Organic Carbon Stocks}

We computed the probability associated with each simulated tillage practice using state level CTIC estimations for the adoption of CT, RT, and conservation tillage (Fig. 2). Then, we calculated a weighted average of model outputs (Fig. 7). The CTIC defines conservation tillage as a practice that leaves at least 30\% of the soil covered by crop residues at planting. We considered NT a proxy for conservation tillage. With actual trends in adoption of RT and NT, SOC stocks to a depth of $20 \mathrm{~cm}$ in cornsoybean croplands since 1980 are shown to increase at a rate of 0.7 tera grams (Tg) per year, reaching $506 \mathrm{Tg}$ in 2019, which is an increase of $28 \mathrm{Tg}$ with respect to the stock in 1980 . Thus, our model simulations indicate that SOC $(0-20 \mathrm{~cm})$ in Iowa's croplands is acting as a net sink for atmospheric $\mathrm{CO}_{2}$. Using the Century model, Paustian et al. (2002) also found that Iowa croplands are acting as a net sink for atmospheric $\mathrm{CO}_{2}$, sequestering 0.4 , 0.8 , and $0.7 \mathrm{Tg} \mathrm{yr}^{-1}$ of SOC under intensively tilled, moderate tilled, or no-tilled cropland, respectively.

In contrast, the EPIC model estimated a decrease of SOC stocks in the soil profile, the rate being $-1.7 \mathrm{Tg} \mathrm{yr}^{-1}$. Hence, SOC stock in the soil profile of Iowa would decrease from $1835 \mathrm{Tg}$ in 1980 to $1771 \mathrm{Tg}$ in 2019. The main reason is EPIC simulating a decrease in profile depth with time because of soil erosion. For example, the model is initialized with a soil profile depth of $1.52 \mathrm{~m}$ in 1970, but the profile depth under CT management at the end of 2019 may be $1.47 \mathrm{~m}$ or less, depending on erosion. Thus, these simulation results are not conclusive, at least when the ending soil profile depth is deeper than EPIC estimations. Our simulations have not addressed sediment deposition processes occurring within the watersheds in Iowa; therefore, soil losses might be overestimated. Overall, this result is in line with the finding of Potter et al. (2006). They estimated that most croplands in Iowa had significant losses of SOC in the soil profile during the last $30 \mathrm{yr}$.

Lee et al. (1993) used an earlier version of EPIC to simulate long-term (100 yr) effect of management practices on soil erosion and $\mathrm{C}$ content at 100 randomly selected sites within the US Corn Belt. They found increases in SOC stocks in the top $15 \mathrm{~cm}$ with increasing adoption of conservation tillage but found decreases in SOC stocks (except when cover crops were used) when a depth of $1 \mathrm{~m}$ from the original surface was considered in calculations. Gal et al. (2007) and Baker et al. (2007) have recently reported that increases in SOC stocks when switching from CT to conservation tillage may be an artifact of the superficial $(0-30 \mathrm{~cm})$ sampling depth considered in most published studies and that tillage comparisons should be based on samples taken well beyond the deepest tillage depth. We agree that the soil depth considered for calculation of SOC stocks is an important factor that needs further investigation.

Another important factor contributing to the uncertainty in calculating the effect of management practices on SOC stocks

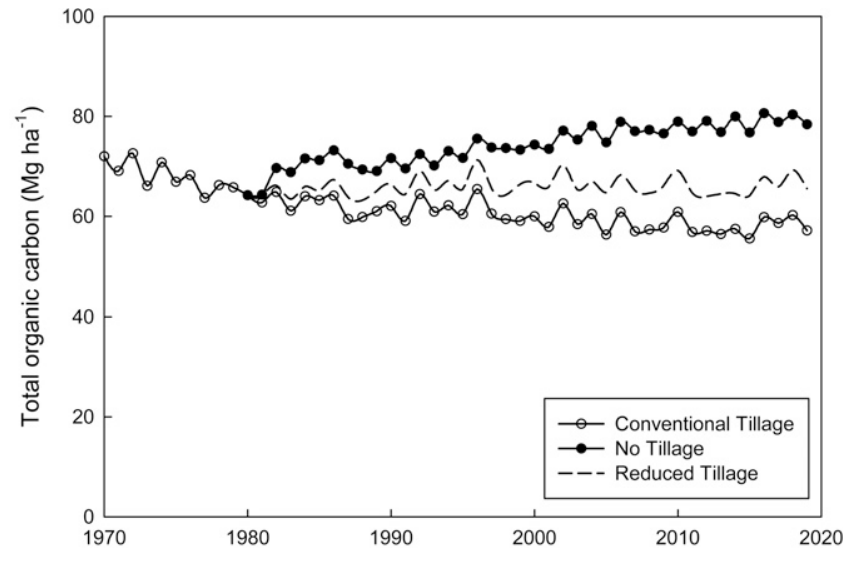

Fig. 6. Simulation results showing the effects of conventional tillage, reduced tillage, and no-tillage practices on soil organic $\mathrm{C}$ stocks $(0-20 \mathrm{~cm})$ in the state of lowa.

at the state level is the need for spatial and temporal information on management practices (i.e., location of fields that use each of the several management systems and how long cropland fields are farmed with continued use of each management system). Napier and Tucker (2001), using a survey approach on a watershed located in northeast Iowa, found that only $12 \%$ of the farmers practiced no-till every year. Hill (2001), us-

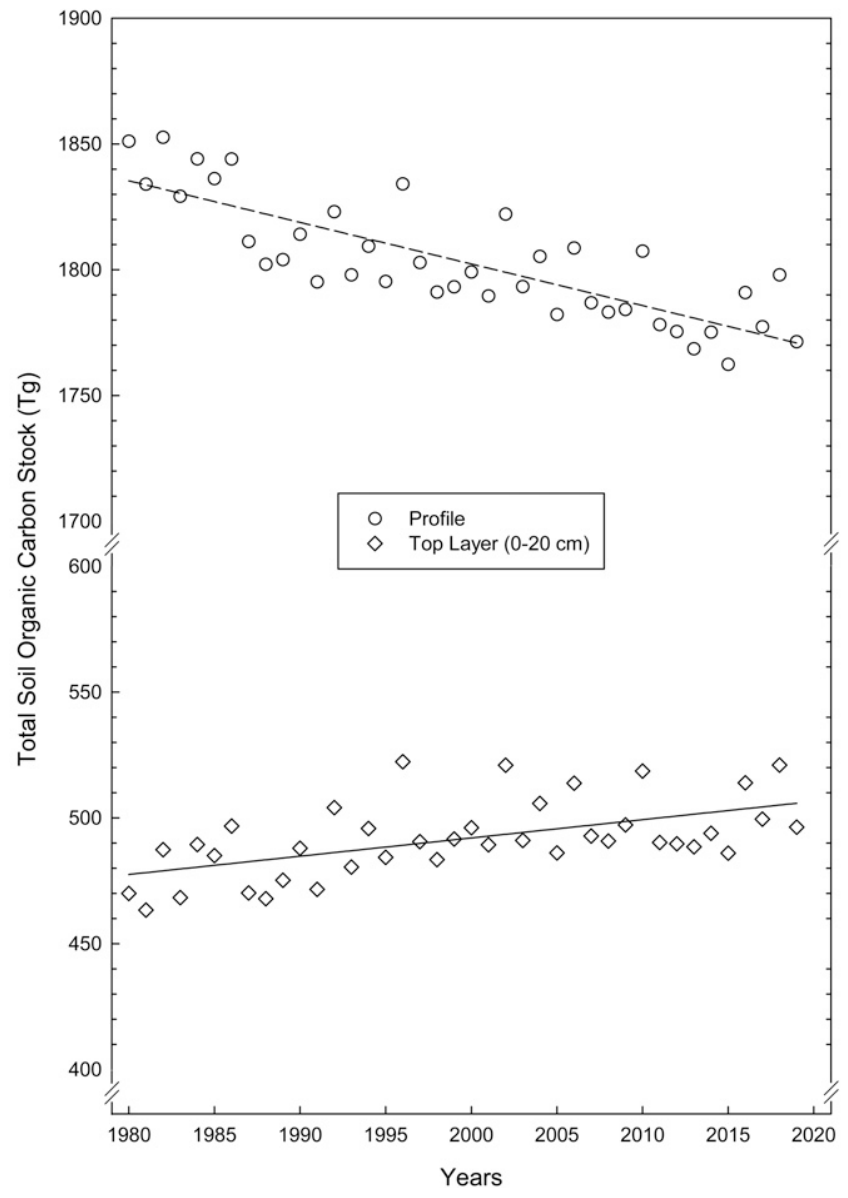

Fig. 7. Simulated temporal changes in soil organic carbon stocks in the soil profile and in the 0 - to $20-\mathrm{cm}$ layer of croplands in the state of lowa. 


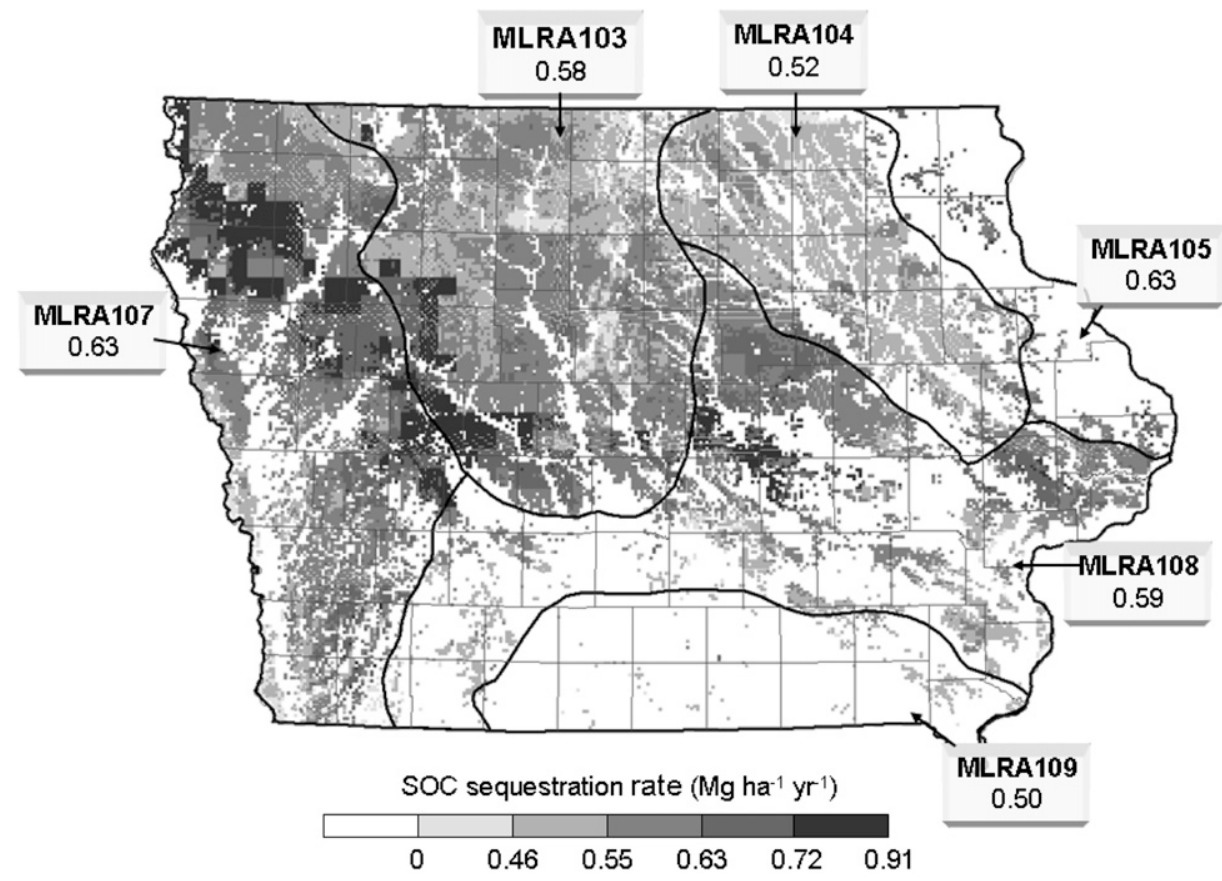

Fig. 8. Simulated soil organic carbon sequestration rates in lowa during 2006. Polygons on the map shows major land resource areas. Numbers in boxes are least-squares means of soil organic carbon (SOC) sequestration rates (Mg ha $\left.{ }^{-1} \mathrm{yr}^{-1}\right)$.

ing a survey approach at the state level, found that during the 1994-1999 period, fields in Iowa had been continuously under NT for 2.3 yr on average. These data suggest that a continuous practice of a particular tillage management seems to be an exception and not the rule. Farmers rotate tillage systems to optimize yields and to control pest and diseases (Hill, 2001).

\section{Soil Organic Carbon Sequestration Rates in 2006}

Sequestration rates were estimated by calculating the difference between RT and CT and between NT and CT in 2006 and dividing this difference by the number of years since conservation tillage began within the simulation run $(25 \mathrm{yr})$. Percentage of croplands under RT or NT was used as a weighting factor. The rate of SOC sequestration when switching from CT to RT or NT ranged from 0 to $0.91 \mathrm{Mg} \mathrm{C} \mathrm{ha}^{-1} \mathrm{yr}^{-1}$ in 2006 (Fig. 8). Polygons in Fig. 8 represent major land resource areas in Iowa and represent areas of similar soil and climate. Data were analyzed for variance (one-way ANOVA) using PROC Mixed in SAS (SAS Institute Inc., 2003) with MLRA as the independent random variable and SOC sequestration rates as dependent variables. Sequestration rates were the highest in MLRAs 107 and 105, with least-squares mean of $0.63 \mathrm{MgC} \mathrm{ha}^{-1} \mathrm{yr}^{-1}$. These MLRAs occupy the drier areas in the state, where the effect of crop residues in reducing soil water evaporation and runoff and increasing infiltration has a higher impact than in wetter areas on crop productivity and the amount of residue returning to the soil. The latter is especially true in MLRA 107 , which has well drained soils on strongly slopping topography. The lowest sequestration rate was estimated for MLRA 109, with $0.50 \mathrm{MgC} \mathrm{ha} \mathrm{yr}^{-1}$. Croplands occupy a small area in MLRA 109 , and the flat topography and poor drainage negatively affect crop productivity and reduce the beneficial impacts of conservation tillage. Sequestration rates were intermediate in MLRAs 103,
104 , and 108, which are located in wetter areas of the state where the impact of crop residues on soil water balance is smaller than in dryer regions (major land resource areas 107 and 105).

Overall, our estimations of SOC sequestration rates agree in magnitude and location with the estimations reported by Paustian et al. (2002). Published data on SOC sequestration rates in Iowa are scarce. A review of the literature (Johnson et al., 2005) showed that SOC sequestration rates in the US Corn Belt region were highly variable $\left(0.54 \pm 0.36 \mathrm{Mg} \mathrm{C} \mathrm{ha}^{-1} \mathrm{yr}^{-1}\right)$. Iowa producers participating in a carbon trading pilot project (Iowa Farm Bureau, 2005) were issued exchange soil offsets at the rate of $0.34 \mathrm{Mg} \mathrm{C} \mathrm{ha}^{-1} \mathrm{yr}^{-1}$ for commitment to conservation tillage (NT, strip-till, or ridge-till). Our study indicates that Iowa producers may receive better compensation for their commitment to SOC sequestration. It also highlights one of many applications that a validated SOC model may have.

\section{Summary and Conclusions}

The EPIC model accurately simulated state averages of corn and soybean yields during a 35-yr period (1970-2005) and adequately simulated surface SOC, as judged by comparison with the few measured data in Iowa. More ground data on spatial and temporal SOC are needed for better model calibration and validation.

Our results suggest that the adoption of conservation tillage positively affects SOC sequestration at the 0 - to 20 -cm depth. If current trends in the adoption of conservation tillage continue, the total stock of SOC $(0-20 \mathrm{~cm})$ in Iowa is predicted to reach $506 \mathrm{Tg}$ in 2019, representing an increase of $28 \mathrm{Tg}$ compared with SOC stocks in 1980, when most croplands were under conventional tillage practices. In contrast, when the whole soil profile was considered, EPIC estimated a decrease of SOC stocks with time, from $1835 \mathrm{Tg}$ in 1980 to $1771 \mathrm{Tg}$ in 2019. The main reason is soil ero- 
sion impacts on soil depth. Soil depth considered for calculation of SOC stocks is an important factor that needs further investigation.

Although we simulated continuous use of RT and NT, most farmers rotate tillage systems. More spatial and temporal information on crop and soil management practices are needed for better estimation of SOC changes at the regional (state) level.

The impacts of conservation agriculture is highest in croplands receiving less rainfall, suggesting that crop residues have a positive effect on water balance through reducing soil evaporation, increasing infiltration, or reducing water runoff.

\section{Acknowledgment}

We appreciate the expert technical support on the EPIC model provided by Dr. R. César Izaurralde, Joint Global Change Research Institute, Pacific Northwest Division Laboratory, College Park, MD, and Dr. Jimmy Williams, Texas Agricultural Experiment Station, Temple, TX. This research was conducted as part of the NASA Carbon Management Project funded under NRA-04-OES-01 program agreement No. NNH05AA42I. The U.S. Department of Agriculture, Agricultural Research Service also provided funding for part of this research. Hector Causarano thanks the support provided by Auburn University, AL, and Universidad Nacional de Asunción, Paraguay.

\section{References}

Al Kaisi, M.M., and X. Yin. 2005. Tillage and crop residue effects on soil carbon and carbon dioxide emission in corn-soybean rotations. J. Environ. Qual. 34:437-445.

Al Kaisi, M.M., X. Yin, and M.A. Licht. 2005. Soil carbon and nitrogen changes as affected by tillage system and crop biomass in a cornsoybean rotation. Appl. Soil Ecol. 30:174-191.

Baker, J.M., T.E. Ochsner, R.T. Venterea, and T.J. Griffis. 2007. Tillage and soil carbon sequestration: What do we really know? Agric. Ecosyst. Environ. 118:1-5.

Causarano, H.J., J.N. Shaw, A.J. Franzluebbers, D.W. Reeves, R.L. Raper, K.S. Balkcom, M.L. Norfleet, and R.C. Izaurralde. 2007. Simulating field-scale soil organic carbon dynamics using EPIC. Soil Sci. Soc. Am. J. 71:1174-1185.

Conservation Technology Information Center. 2005. National crop residue management survey, conservation tillage data, West Lafayette, IN. CTIC, West Lafayette, IN.

Gal, A., T.J. Vyn, E. Michéli, E.J. Kladivko, and W.W. McFee. 2007. Soil carbon and nitrogen accumulation with long-term no-till versus moldboard plowing overestimated with tilled-zone sampling depths. Soil Tillage Res. 96:42-51.

Gassman, P.W., J.R. Williams, V.W. Benson, R.C. Izaurralde, L.M. Hauck, C.A. Jones, J.D. Atwood, J.R. Kiniry, and J.D. Flowers. 2004. Historical development and applications of the EPIC and APEX models (ASAE Paper No. 042097). ASAE, St. Joseph, MI.

Follett, R.F. 2001. Soil management concepts and carbon sequestration in cropland soils. Soil Tillage Res. 61:77-92.

Hill, P.R. 2001. Use of continuous no-till and rotational tillage systems in the central and northern Corn Belt. J. Soil Water Conserv. 56:286-290.

Iowa Farm Bureau. 2005. Carbon credit aggregation pilot project. Available at http://www.iowafarmbureau.com/special/carbon (verified 22 Mar. 2007).

Iowa State University. 2007. Agronomy extension. Corn and soybean production. Iowa State Univ., Ames, IA. Available at http://www. agronext.iastate.edu (verified 4 Feb. 2008).

Izaurralde, R.C., J.R. Williams, W.B. McGill, N.J. Rosenberg, and M.C.Q. Jakas. 2006. Simulating soil C dynamics with EPIC: Model description and testing against long-term data. Ecol. Modell. 192:362-384.

Johnson, J.M.F., D.C. Reicosky, R.R. Allmaras, T.J. Sauer, R.T. Venterea, and C.J. Dell. 2005. Greenhouse gas contributions and mitigation potential of agriculture in the central USA. Soil Tillage Res. 83:73-94.
Karlen, D.L., A. Kumar, R.S. Kanwar, C.A. Cambardella, and T.S. Colvin. 1998. Tillage system effects on 15 -year carbon-based and simulated N budgets in a tile-drained Iowa field. Soil Tillage Res. 48:155-165.

Kiniry, J.R., B. Bean, Y. Xie, and P. Chen. 2004. Maize yield potential: Critical processes and simulation modeling in a high-yielding environment. Agric. Syst. 82:45-56.

Kiniry, J.R., D.J. Major, R.C. Izaurralde, J.R. Williams, P.W. Gassman, M. Morrison, R. Bergentine, and R.P. Zentner. 1995. EPIC model parameters for cereal, oilseed, and forage crops in the northern Great Plains region. Can. J. Plant Sci. 75:679-688.

Kiniry, J.R., J.R. Williams, P.W. Gassman, and P. Debaeke. 1992. A general, process-oriented model for two competing plant species. Trans. ASAE 35:801-810.

Kiniry, J.R., J.R. Williams, R.L. Vanderslip, J.D. Atwood, D.C. Reicosky, J. Muliken, W.J. Cox, H.J. Masacgni, S.E. Hollinger, and W.J. Wiebold. 1997. Evaluation of two maize models for nine U.S. locations. Agron. J. 89:421-426.

Lal, R. 2002. Why carbon sequestration in agricultural soils. p. 21-30. In J.M. Kimble et al. (ed.) Agricultural practices and policies for carbon sequestration in soil. CRC Press, Boca Raton, FL.

Lee, J.J., D.L. Phillips, and R. Liu. 1993. The effect of trends in tillage practices on erosion and carbon content of soils in the U.S. Corn Belt. Water Air Soil Pollut. 70:389-401.

Lindquist, J.L., T.J. Arkebauer, D.T. Walters, K.G. Cassman, and A. Dobermann. 2005. Maize radiation use efficiency under optimal growth conditions. Agron. J. 97:72-78.

Moorman, T.B., C.A. Cambardella, D.E. James, D.L. Karlen, and L.A. Kramer. 2004. Quantification of tillage and landscape effects on soil carbon in small Iowa watersheds. Soil Tillage Res. 78:225-236.

Napier, T.L., and M. Tucker. 2001. Use of soil and water protection practices among farmers in three Midwest watersheds. Environ. Manage. 27:269-279.

Parton, W.J., D.S. Schimel, C.V. Cole, and D.S. Ojima. 1987. Analysis of factors controlling soil organic matter levels in Great Plains grasslands. Soil Sci. Soc. Am. J. 51:1173-1179.

Paustian, K., J. Brenner, K. Killian, J. Cipra, S. Williams, E.T. Elliott, M.D. Eve, T. Kautza, and G. Bluhm. 2002. State-level analyses of C sequestration in agricultural soils. p. 193-204. In J.M. Kimble et al. (ed.) Agricultural practices and policies for carbon sequestration in soil. CRC Press, Boca Raton, FL.

Paustian, K., E.T. Elliott, H.P. Collins, C.V. Cole, and E.A. Paul. 1995. Use of a network of long-term experiments in North America for analysis of soil C dynamics and global change. Aust. J. Exp. Agric. 35:929-939.

Pedersen, P., and J.G. Lauer. 2004. Soybean growth and development in various management systems and planting dates. Crop Sci. 44:508-515.

Potter, S.R., S. Andrews, J.D. Atwood, R.L. Kellog, J. Lemunyon, L. Norfleet, and D. Oman. 2006. Model simulation of soil loss, nutrient loss, and change in soil organic carbon associated with crop production. Available at http://www.nrcs.usda.gov/technical/nri/ceap/ croplandreport (verified 4 Feb. 2008).

SAS Institute. 2003. The SAS system for Windows. Release 9.1. SAS Inst., Cary, NC.

SCAS. 2005. Spatial Climate Analysis Service. Oregon State Univ., Corvallis, OR. Available at http://www.ocs.oregonstate.edu/prism (verified 4 Feb. 2008).

Tollenaar, M., and A. Aguilera. 1992. Radiation use efficiency of an old and a new maize hybrid. Agron. J. 84:536-541.

USDA-ERS. 2007. U.S. Fertilizer Use and Price. USDA, Washington, DC. Available at http://www.ers.usda.gov/Data/FertilizerUse/ (verified 4 Feb. 2008).

USDA-NASS. 2002. Census of Agriculture. Table 1. State Summary Highlights: 2002. USDA, Washington, DC. Available at http://www.nass.usda.gov/ census/census02/volume1/us/index2.htm (verified 4 Feb. 2008).

USDA-NASS. 2007. Quick Stats. USDA, Washington, DC. Available at http://www.nass.usda.gov (verified 4 Feb. 2008).

Wang, X., X. He, J.R. Williams, R.C. Izaurralde, and J.D. Atwood. 2005. Sensitivity and uncertainty analyses of crop yields and soil organic carbon simulated with EPIC. Trans. ASAE 48:1041-1054.

Westgate, M.E., F. Forcella, D.C. Reicosky, and J. Somsen. 1997. Rapid canopy closure for maize production in the northern U.S. Corn Belt: Radiation-use efficiency and grain yield. Field Crops Res. 49:249-258.

Williams, J.R. 1990. The erosion-productivity impact calculator (EPIC) model: A case history. Phil. Trans. R. Soc. London 329:421-428. 